\title{
PROSES PEMEROLEHAN BAHASA: \\ DARI KEMAMPUAN HINGGA KEKURANGMAMPUAN BERBAHASA
}

\author{
Rohmani Nur Indah
}

Dosen Jurusan Bahasa dan Sastra Inggris,

Fakultas Humaniora dan Budaya, Universitas Islam Negeri (UIN) Malang.

Jalan Gajayana No. 50 Telepon (0341) 570872, Faksimile (0341) 570872 Malang 65144

\begin{abstract}
Studies on language acquisition become the pillar of Psycholinguistics as a branch of Applied Linguistics that deals with the relationship between human's thought and language as well as how human beings comprehend, acquire and develop their language. Language acquisition does not merely involve children's first or second language development, but also temporer language disorder -which does not belong to permanent language disorder. Deviation on language development to some extent gets little attention from psycholinguists. Most references on psychology of language discuss language disorder in general, whereas the current issues on this area are still rarely found. The following article deciphers what and how language acquisition can be done and cannot be completed.
\end{abstract}

\section{Key words}

Language Acquisition, Psycolinguistics, Children

\section{Pendahuluan}

"Manusia berbahasa ibarat burung bersayap", demikian kata George H. Lewis. Bahasa tak terlepas dari hakikat keberadaan manusia karena itulah yang menjadi piranti komunikasi antar manusia. Pada ungkapan 
di atas nampak bahwa manusia tanpa bahasa sama seperti burung tanpa sayap, karena sayaplah yang mecirikan burung dan bahasalah yang mencirikan manusia.

Noam Chomsky, bapak Linguistik dunia, menyebutkan bahwa jika kita mempelajari bahasa maka pada hakikatnya kita sedang mempelajari esensi manusia, yang menjadikan keunikan manusia itu sendiri. Manusia dirancang untuk berjalan, tetapi tidak diajari agar bisa berjalan. Demikian pula dalam berbahasa, tidak seorangpun bisa diajari bahasa karena manusia diciptakan untuk berbahasa. Dalam artian bahwa pada kenyataannya manusia akan berbahasa tanpa bisa dicegah agar dia tidak memperoleh bahasa.

Bahasa dikatakan menjadi keunikan yang mencirikan manusia dan membedakannya dengan makhluk hidup lainnya. Pernyataan ini tidak berarti bahwa hanya manusia yang memiliki piranti komunikasi. Binatang disebut tidak berbahasa tapi tetap bisa berkomunikasi. Ocehan burung kakatua yang bisa menyerupai ucapan manusia; perintah 'duduk' atau 'kejar' yang dipahami anjing; kemampuan monyet untuk memahami perintah ujaran manusia; nyanyian burung yang berirama; tempo bunyi yang didengungkan lebah; suara-suara yang dikeluarkan ikan paus; semua itu adalah contoh piranti komunikasi binatang. Piranti ini tidak serta merta disebut bahasa walaupun memang menyerupai bahasa.

Contoh piranti komunikasi di atas tidak menyandang sebutan bahasa karena tidak memenuhi prasyarat bahasa seperti: unsur pertukaran pesan dari pembicara pada pendengar dan sebaliknya; adanya umpan-balik dari pembicara; kebermaknaan dan pembedaan unit-unit kosakata; adanya proses transmisi kultural yang melatarbelakangi ujaran; munculnya kreatifitas dan kemampuan pemolaan unit bahasa; pengendalian maksud bicara dan peralihan giliran bicara, serta penggunaan ungkapan yang bukan bermakna literal.

Ciri-ciri di atas dicetuskan pertama kali oleh Charles Hockett (1963) yang kemudian melahirkan pro-kontra seputar pengistilahan 
bahasa. Linguis lain menyebutkan bahwa keutamaan bahasa adalah pada kebermaknaan dan fungsi komunikatifnya. Namun demikian kompleksitas berbahasa kurang menjadi titik tekannya. Field kemudian mengkategorikan ciri-ciri tersebut ke dalam kelompok-kelompok yang meliputi saluran bahasa, ciri-ciri semantis, pembelajaran, struktur, dan fungsi (Field, 2003:40).

Dari paparan di atas, nyatalah bahwa hanya manusia yang layak disebut berbahasa mengingat kompleksnya kebahasaan itu sendiri. Kembali pada pendapat Chomsky tadi, manusia sejak lahir akan mempelajari bahasa dengan sendirinya, meski serumit apapun anak akan memperoleh bahasa. Proses pemerolehan ini berlangsung secara alami, tidak dengan cara menghapalkan kosakata, aturan-aturan gramatika, dan aplikasi secara sosial. Kamus bahasa dalam otak anak tersusun secara otomatis tanpa teori, sedangkan kemampuan gramatika anak terasah dari pemerolehan yang disimaknya.

Perihal pemerolehan bahasa dan seluk beluknya menjadi tema kajian Psikolinguistik yang merupakan studi psikologi bahasa yang mengulas proses mental yang terjadi pada penggunaan dan pemerolehan bahasa. Studi ini terkait dengan disiplin ilmu lainnya, misalnya: linguistik, yang mengkaji struktur dan perubahan bahasa; neurolinguistik, yang mempelajari hubungan antara otak dan bahasa; serta sosiolinguistik, yang membahas tentang hubungan antara bahasa dan perilaku sosial (Field, 2003:40).

Dalam pembahasan berikut ini akan dikupas perkembangan bahasa pada anak yang kemudian mengarah pada paparan tentang pemerolehan bahasa pertama dan kedua pada anak sebelum pada akhirnya mengangkat tentang gangguan berbahasa.

\section{Perkembangan Bahasa pada Anak dan Ragamnya}

Perkembangan bahasa merupakan salah satu mata rantai pertumbuhan anak selain perkembangan lain seperti perkembangan motorik kasar, perkembangan pemecahan masalah visuo-motor yang 
merupakan gabungan fungsi penglihatan dan motorik halus, serta perkembangan sosial.

Perkembangan bahasa sering menjadi tolok ukur tingkat intelejensi anak meskipun pada hakikatnya perkembangan seorang anak merupakan suatu kesatuan yang utuh dan saling melengkapi. Artinya seorang anak tidak dapat dikatakan cerdas jika dia hanya bisa memecahkan masalah visuo-motor dan fasih berbahasa tanpa diimbangi kemampuan bersosialisasi.

Setiap anak yang normal pertumbuhan pikirannya akan belajar B1 atau bahasa ibu dalam tahun-tahun pertama dalam hidupnya, dan proses ini terjadi hingga kira-kira umur 5 tahun. Sesudah itu pada masa pubertas (sekitar 12-14 tahun) hingga menginjak dewasa (sekitar 18-20 tahun), anak itu akan tetap belajar B1. Sesudah pubertas ketrampilan bahasa anak tidak banyak kemajuannya, meskipun dalam beberapa hal, umpamanya dalam kosakata, ia belajar B1 terus menerus selama hidupnya. Pemerolehan B1 kita anggap bahasa yang utama bagi anak karena bahasa ini yang paling mantap pengetahuan dan penggunaannya.

Ketika seorang anak sedang memperoeh bahasa B1-nya, terjadi dua proses, yaitu proses kompetensi dan proses performasi. Kedua proses ini merupakan dua proses yang berlainan. Kompetensi adalah proses penguasaan tata bahasa yang berlangsung secara tidak disadari. Proses kompetensi ini menjadi syarat untuk terjadinya proses performasi yang menyangkut proses pemaham dan proses memproduksi ujaran. Proses pemahaman melibatkan kemampuan mempersepsi kalimat yang didengar. Sedangkan proses memproduksi ujaran menjadi kemapuan linguistik selanjutnya.

Fungsi berbahasa merupakan fungsi yang paling kompleks di antara seluruh faset perkembangan sebagaimana yang dijabarkan di atas. Indikator perkembangan bahasa ini meliputi fungsi reseptif -yaitu kemampuan anak untuk mengenal dan bereaksi terhadap seseorang, terhadap kejadian lingkungan sekitarnya, mengerti maksud mimik dan suara dan akhirnya kata-kata-dan fungsi ekspresif, yaitu Kemampuan 
anak mengutarakan keinginannya dan pekirannya. Fungsi ekspresif ini dipengaruhi fungsi reseptif dan merupakan kemampuan yang lebih kompleks mengingat anak memulai dengan komunikasi preverbal, dilanjutkan komunikasi dengan ekspresi wajah, gerakan tubuh, dan pada akhirnya dengan menggunakan kata-kata atau komunikasi verbal (Pusponegoro, 1997:80).

Tabel berikut meringkas tahapan perkembangan bicara pada anak yang meliputi fungsi reseptif dan ekspresif dimulai sejak bayi baru lahir hingga berumur 4 tahun.

Tabel.1

Tahap perkembangan bicara pada anak

\begin{tabular}{|c|c|c|c|}
\hline \multicolumn{2}{|l|}{ Fungsi reseptif } & \multicolumn{2}{|c|}{ Fungsi ekspresif } \\
\hline Perkembangan & Usia & Perkembangan & Usia \\
\hline Bereaksi terhadap suara & lahir & Oooo-ooo & 6 minggu \\
\hline Tersenyum sosial & 5 minggu & Guu-guu & 3 bulan \\
\hline Orientasi terhadap suara & 4 bulan & A-guu, a-guu & 4 bulan \\
\hline \multirow{2}{*}{$\begin{array}{l}\text { Menoleh pada suara bel } \\
\text { - Fase I } \\
\text { - Fase II } \\
\text { - Fase III }\end{array}$} & \multirow{2}{*}{$\begin{array}{l}5 \text { bulan } \\
7 \text { bulan } \\
9 \text { bulan }\end{array}$} & Mengoceh & $4-6$ bulan \\
\hline & & $\begin{array}{l}\text { Dadada } \\
\text { (menggumam) }\end{array}$ & 6 bulan \\
\hline $\begin{array}{l}\text { Mengerti perintah 'tidak } \\
\text { boleh' }\end{array}$ & 8 bulan & $\begin{array}{l}\text { Da-da tanpa arti } \\
\text { Ma-ma tanpa arti }\end{array}$ & 8 bulan \\
\hline \multirow{2}{*}{$\begin{array}{l}\text { Mengerti perintah } \\
\text { ditambah mimic }\end{array}$} & \multirow[t]{2}{*}{11 bulan } & Dada & 10 bulan \\
\hline & & $\begin{array}{l}\text { Mama, kata } \\
\text { pertama }\end{array}$ & 11 bulan \\
\hline $\begin{array}{l}\text { Mengerti perintah tanpa } \\
\text { mimik }\end{array}$ & 14 bulan & $\begin{array}{l}\text { Kata kedua dan } \\
\text { ketiga }\end{array}$ & $12-13$ bulan \\
\hline \multirow{2}{*}{$\begin{array}{l}\text { Menunjuk } 5 \text { bagian } \\
\text { badan yang disebutkan }\end{array}$} & \multirow[t]{3}{*}{17 bulan } & $4-6$ kata & 15 bulan \\
\hline & & $7-10$ kata & 17 bulan \\
\hline & & Kalimat pendek 2 & 21 bulan \\
\hline
\end{tabular}




\begin{tabular}{|l|l|} 
kata & \\
\hline $\begin{array}{l}50 \text { kata, } \\
\text { kalimat terdiri } \\
\text { dari 2 kata }\end{array}$ & 2 tahun \\
\hline $\begin{array}{l}250 \text { kata, } \\
\text { kalimar terdiri } \\
\text { dari 3 kata }\end{array}$ & 3 tahun \\
\hline $\begin{array}{l}\text { Kalimat terdiri } \\
\text { dari 4-5 kata, } \\
\text { bercerita } \\
\text { Menanyakan arti } \\
\text { kata } \\
\text { Menghitung }\end{array}$ \\
sampai 20 & \\
\hline
\end{tabular}

Dengan mengacu pada tabel perkembangan bicara di atas, maka anak dikatakan mengalami keterlambatan bicara atau kesulitan berbahasa jika kemampuannya menyimpangan dari standar tersebut. Keterlembatan bicara terjadi pada 3-15\% anak, dan merupakan kelainan perkembangan yang paling sering terjadi. Dari jumlah tersebut, sebanyak $1 \%$ anak yang mengalami keterlambatan bicara tetap tidak dapat berbicara. 30\% dari anak dengan keterlambatan ringan akan sembuh -atau menjadi normal- dengan sendirinya. Sisanya, $70 \%$ akan mengalami kesulitan berbahasa, kurang pandai, atau mengalami kesulitan belajar lainnya.

Penyebab keterlambatan bicara dan berbahasa secara umum sangat beragam, diantaranya: 1) retardasi mental yang menyebabkan kurangnya kepandaian anak dibandingkan anak lain seusianya, 2) gangguan pendengaran, 3) kelainan organ bicara, 4) mutisme selektif atau ketidakmauan berbicara pada keadaan tertentu, 5) deprivasi atau kurangnya stimuli dari lingkungan, 6) kekurangan gizi yang mengakibatkan kelainan saraf, dan 7) autisme atau deviansi komunikasi baik dalam berbahasa maupun bertingkah laku yang sedang tren dibicarakan saat ini (Sutardi, 1997:67). 
Kajian tentang keterlambatan atau gangguan bicara di beberapa literatur psikologi bahasa masih terbatas pada kesulitan berbicara dalam tataran umum. Kesulitan berbicara yang megkerucut pada kemampuan berbahasa dari tinjauan sitaksis dan pragmatis belum banyak diangkat. Carrol (1986:30) menggolongkan gangguan bicara menjadi 4 (empat), yaitu: 1) gangguan bicara pada anak dengan keterlambatan mental, 2) gangguan bicara pada anak-anak penderita tunarungu, 3) gangguan bicara pada anak penyandang autisma, dan 4) gangguan bicara pada anak yang mengalami cidera otak.

\section{Pemerolehan Bahasa Pertama pada Masa Awal}

Pemerolehan bahasa pada anak yang baru lahir berawal dari suara tangisnya yang menjadi bentuk respon terhadap stimuli dari lingkungannya. Caranya merespon akan berkembang seiring kematangan mentalnya. Selanjutnya anak akan terus menyimpan stimuli bahasa pada memorinya.

Pemerolehan bahasa pertama, atau yang kerap disebut bahasa ibu, merupakan proses kreatif dimana aturan-aturan bahasa dipelajari anak berdasarkan input yang diterimanya dari bentuk tersederhana hingga bentuk yang paling kompleks.

Anak akan lebih cepat menguasai bahasa jika ia memperoleh bahasa dalam masa emas atau periode ideal (critical age) yaitu usia 6-15 tahun. Pada teori lain diasumsikan bahwa usia kritis tersebut berkisar 06 tahun, namun pada intinya batasan periode ideal yang dimaksud adalah prapubertas. Menurut Lanneberg (dalam Subyakto, 1992) pada masa emas otak manusia masih sangat elastis sehingga memungkinkan seorang anak memperoleh bahasa pertama dengan mudah dan cepat. Adapun pada usia pubertas telah dicapai kematangan kognitif pada saat selesainya fungsi-fungsi otak tertentu, khususnya fungsi verbal yang menjadi mantap di bagian otak sebelah kiri. Hal inilah yang disebut lateralisasi. Masa kritislah yang bertanggung jawab atas lateralisasi yang membuat proses pemerolehan bahasa secara alamiah akan berkurang hingga akhirnya hilang sama sekali. 
Efektifnya pemerolehan bahasa pada usia tersebut telah diujikan dalam beberapa penelitian. Hipotesis bahwa periode usia di atas disebut masa emas pemerolehan bahasa diperkuat oleh beberapa kasus keterlambatan bicara pada orang dewasa yang memperoleh bahasa di atas usia 15 tahun. Sebut saja beberapa nama seperti Amila dan Kayla yang ditemukan di belantara India pada tahun 1920; Genie yang terisolir dari kehidupan manusia dan segala kontak sosial hingga tahun 1970; dan Victor yang ditemukan di hutan Aveyson pada tahun 1978. Nama yang terakhir ini kisah hidupnya difilmkan dimana diceritakan tentang betapa sulitnya mengembalikan anak pada kemampuan berbahasa dan berkomunikasi secara sosial dengan seutuhnya. Keterlambatan pemerolehan bahasa berakibat ketidakmampuan secara sepenuhnya penguasaan morfologis dan sintaktika bahasa (Field, 2003:73).

Contoh kasus keterlambatan pemerolehan bahasa terjadi pada Chelsea yang mulai memperoleh bahasa saat berusia 31 tahun. Bermula dari kecerobohan diagnosis dokter yang menyebutkan bahwa Chelsea mengalami keterlambatan mental, dia tidak pernah dilibatkan dalam kontak sosial yang memungkinkan pemerolehan bahasanya. Setelah beranjak dewasa baru diketahui bahwa Chelsea menderita tuli yang sebetulnya bisa diatasi dengan diajari bahasa isyarat. Setelah dipasang alat bantu dengar, ternyata Chelsea bisa berbicara dan menirukan ucapan orang lain. Waktu yang dibutuhkan Chelsea lebih lama dibandingkan waktu pemerolehan bahasa anak pada masa emas.

Hasil penelitian lain menyebutkan bahwa anak yang diajarkan menggunakan bahasa isyarat pada usia 0-6 tahun lebih baik dalam pemahaman dan produksi kata daripada yang belajar pada usia 12 tahun ke atas. Kesimpulannya, di atas masa emas otak manusia tidak bisa secara maksimal memperoleh kemampuan sintaktik dan morfologis. Dus, adalah benar bahwa ada ungkapan mengajari (bahasa, membaca, mengaji, dll.) anak kecil adalah bagaikan menulis di atas batu dan mengajari orang tua bagaikan menulis di atas air.

Kemampuan menggunakan bahasa dalam proses pemerolehan bahasa secara sistimatis dan akurat memang tidak mudah. Pernyataan 
ini diperkuat oleh studi Bellugi dan Klima (dalam Fromkin, 1999) yang menunjukkan bahwa anak tunarungu yang tumbuh dan dibesarkan oleh orang tua tunarungu dapat menguasai bahasa isyarat. Kemampuan memproduksi kata anak tunarungu ternyata lebih cepat dibandingkan kemampuan memproduksi kata pada anak normal. Tidak mudahnya pemerolehan kemampuan ini membuktikan bahwa pengendalian otot larinks dan organ bicara pada anak normal lebih kompleks jika dibandingkan dengan pengendalian otot tangan pada anak tunarungu.

Pada kasus di atas tidak bisa diasumsikan bahwa bahasa isyarat lebih mudah dibandingkan bahasa lisan karena keduanya memiliki kesamaan dalam hal universalitas linguistik, sistim gramatika, memungkinkan terjadinya perkembangan dan perubahan kebahasaan, dan tidak terlepas dari adanya faktor kesilapan berbahasa.

\section{Pemerolehan Bahasa Kedua dan Kesulitannya}

Pemerolehan bahasa selain penguasaan bahasa ibu atau bahasa pertama disebut bahasa kedua, ketiga dan seterusnya. Dalam masyarakat Jawa misalnya, bahasa Indonesia disebut sebagai bahasa kedua jika anak dibesarkan dalam komunitas wicara bahasa Jawa.

Pemerolehan bahasa lebih baik jika diawali sejak dini. Mc Laughin dan Genesee, pakar psikolinguistik, berpendapat bahwa anak akan lebih cepat belajar bahasa tanpa kesukaran dibandingkan dengan orang dewasa. Selain itu Eric H. Lennenberg, seorang pakar neurolinguistik, juga menegaskan bahwa kondisi otak mendukung pendapat tersebut. Sebelum masa pubertas, otak atau daya pikir anak lebih lentur dan plastis sehingga dapat diajari bahasa apapun dengan lebih mudah. Daya penyerapan bahasa pada anak berfungsi secara otomatis, cukup dengan self-exposure atau dilibatkan dalam komunikasi partisipatif dalam bahasa target. Pasca pubertas kelenturan ini akan berkurang dan pencapaiannya tidak maksimal (Field, 2003:84).

Secara umum ada dua pendapat mengenai pemerolehan bahasa kedua. Pertama, anak sejak lahir sudah dibiasakan terekspos dengan berbagai bahasa. Kedua, anak belajar bahasa kedua setelah bahasa ibu 
dapat diucapkan dengan baik. Kedua pendapat ini sama baiknya, namun demikian tetap memiliki kekurangan. Metode pertama dapat berakibat munculnya keterlambatan berbicara karena otak anak bekerja keras memetakan bahasa apa yang digunakan oleh orang yang mengajaknya berbicara. Namun hal ini tidak berlangsung lama, saat anak makin besar kemampuan itu akan terasah dengan sendirinya. Metode kedua mengakibatkan pelafalan bahasa kedua akan lebih buruk daripada anak dengan metode pertama. Anak dalam metode pertama akan terbiasa dengan pengucapan dan aksen yang lebih jelas. Sungguhpun begitu, kedua metode ini dapat dipakai dengan catatan memperhatikan suasana pemerolehan bahasa yang bersifat interaktif, motivatif dan atraktif.

Kesulitan pada pemerolehan bahasa kedua masih terkait dengan teori masa emas seperti yang dijelaskan di atas. Secara umum kita melihat bahwa kemudahan anak belajar bahasa makin lama makin berkurang setelah umur 5-7 tahun, sampai menjadi agak sukar dan lambat setelah pubertas sehingga orang jarang mencapai kefasihan fonologi bahasa kedua jika ia mempelajarinya sesudah pubertas atau setelah berakhirnya masa emas. Namun demikian, menurut Schovel dan Krashen kemampuan belajar bahasa kedua tidak berkurang terlalu banyak meskipun proses laterlisasi telah usai (Subyakto-Nababan, 1992:66)

\section{Gangguan berbahasa}

Dalam hal ini yang perlu diperhatikan adalah bahwa gangguan berbahasa berdampak pada 2 (dua) hal. Pertama, Lambat dalam pemerolehan bahasa - sebagai contoh, anak berusia lima tahun memiliki kompetensi bahasa setara dengan anak usia dua tahun. Kedua, Menyimpang dari bentuk baku pada anak yang memperoleh bahasa dengan urutan yang berbeda dari kebanyakan anak, atau anak tersebut memiliki kemampuan yang sangat berbeda dari penutur asli bahasanya sendiri. 
Adapun jika ditinjau dari asalnya, gangguan berbahasa dapat dikategorikan kedalam 2 (dua) kelompok. Pertama, gangguan berbahasa yang berkembang, artinya gangguan akibat kelainan yang dibawa sejak lahir. Pada sebagian anak, terjadi kesulitan dalam pemerolehan bahasa akibat kelainan tumbuh kembang. Kedua, gangguan berbahasa yang diperoleh, artinya gangguan akibat operasi, stroke, kecelakaan atau penuaan.

Gangguan berbahasa dan berkomunikasi dapat diakibatkan faktor medis dan faktor lingkungan. Faktor medis berimplikasi pada gangguan berbicara, gangguan berbahasa dan gangguan berpikir. Contoh faktor medis yaitu gangguan sebagai akibat cidera otak yang menyebabkan kerusakan sistem syaraf, gangguan psikogenik, dan gangguan pada sistem mekanisme organ wicara. Demikian pula halnya dengan kerusakan sistem saraf yang menyebabkan terputusnya jaringan antara wilayah auditori dan produksi tutur sehingga pesan ujaran tidak tersampaikan.

Permasalahan berbicara sebagaimana yang dijelaskan di atas bersifat permanen yang menyebabkan ketidakmampuan berbahasa secara baik dan benar. Adapun beberapa gangguan lain bersifat temporer sehingga mengakibatkan kekurangmampuan berbahasa. Disebut kurang karena tidak mengacu pada kata "tidak" melainkan "belum". Misalnya pada penderita gagap yang disebabkan pengaruh perasaan afektif sehingga pikiran dan ucapan tidak bersambung dengan baik, kesukaran melafalkan kata-kata tertentu dan kurang menguasai topik pembicaraan (Gleason dan Ratner, 1998:75).

Kekurangmampuan berbahasa sebagaimana dijelaskan di atas pada hakikatnya dapat terjadi pada tiga tahapan rekonstruksi ingatan kebahasaan yang membangun proses pemerolehan bahasa secara lengkap. Tahapan pertama yaitu masukan. Pada saat seseorang mendengar atau membaca suatu wacana ia membuat catatan mengenai isi atau pesan kebahasaan sekaligus membuat interpretasi. Pada penderita gangguan neurologis tahap ini mempersulit proses interpretasi sehingga menghalangi keberlangsungan proses selanjutnya. 
Tahapan kedua yaitu penyimpanan. Para ahli membedakan dua konsep penyimpanan yaitu penyimpanan jangka pendek dan jangka panjang. Penyimpanan jangka pendek berupa kata-kata atau angka sejumlah maksimal 7 frase sehingga orang dapat mengingat 7 digit nomor telepon dalam jangka waktu pendek. Adapun penyimpanan jangka panjang menyangkut pesan kalimat yang dapat dipelihara untuk jangka waktu lama yang berbeda dari satu individu ke individu yang lain. Yang terakhir yaitu tahap hasil dimana terjadi kontras antara kedua jenis ingatan, artinya makin lama seorang pendengar mendapat kesempatan mengingat suatu ujaran, makin sedikit bentuk yang diingat, sebaliknya makin banyak makna yang diingat.

Baik ketidakmampuan maupun kekurangmampuan berbahasa yang diartikan sebagai gangguan bicara permanen dan temporer dapat dikategorikan ke dalam 3 (tiga) jenis. Pertama, gangguan dalam mengkondisikan ketidaksempurnaan organ. Kedua, gangguan berkognisi. Ketiga, gangguan mengolah informasi linguistik.

Contoh kategori pertama di atas yaitu yang dialami tunarungu, tunanetra dan penyandang gangguan mekanisme berbicara. Ketidaksempurnaan organ menyebabkan pendidikan tunarungu diprioritaskan pada pengajaran bahasa isyarat. Dengan menggunakan bahasa isyarat sebagai bahasa ibu, tunarungu kemudian memahami bahasa lisan dan tulis sebagai bahasa kedua. Dewasa ini mengajarkan pemahaman membaca gerak bibir lebih ditekankan. Namun demikian bagi penderita tunarungu dengan kerusakan pendengaran yang sangat parah hanya dapat diajari dengan bahasa isyarat.

Mengingat rumitnya fase belajar bahasa anak tunarungu yang bertingkat dari bahasa isyarat dan membaca gerak bibir, sebagai imbasnya dibutuhkan waktu yang lebih lama untuk belajar membaca dan menulis. Oleh karenanya kemampuan baca tulis anak tunarungu lebih lambat dibandingkan anak normal. Keterampilan komunikasi yang dicapai terbatas pada komunikasi tatap muka atau face-to-face, dengan demikian tanpa teknologi visual sulit dilakukan percakapan pertelepon. 
Secara umum perkembangan bahasa pada anak tunarungu ditentukan oleh 3 (tiga) faktor mendasar, yaitu: 1) tingkat kerusakan pendengaran, 2) status pendengaran orang tua (apakah normal atau tunarungu), dan 3) usia diperkenalkan pada sistem komunikasi tertentu serta konsistensi latihan berkomunikasi (Carrol, 1986:65).

Pada penderita tunanetra beberapa keraguan mengenai kemampuannya berbahasa kerap dilontarkan. Salah satu pertanyaan yang sering muncul yaitu apakah kelainan visual mengakibatkan keterlambatan dalam memperoleh bahasa? Hal ini mengingat kondisi anak yang tidak terbantu dengan ekspresi wajah, bahasa tubuh atau pandangan pada obyek disekitarnya. Riset membuktikan bahwa anak tunanetra ternyata memperoleh sistem fonologi lebih lambat daripada anak normal. Anak tunanetra kadang-kadang bingung dengan fonem yang mirip dalam pengucapan, misalnya /n/ dan /m/. Kemampuan anak tunanetra sama dengan anak normal ketika mulai meracau dan mengatakan kata-kata pertama. Namun demikian terdapat perbedaan pada isi kosakata awal mereka. Anak tunanetra umumnya kurang memvariasikan kata kerja, hal ini menunjukkan bahwa mereka memiliki keterbatasan pengkategorian yang berdampak pada keberagaman kosakatanya.

Ketidaksempurnaan organ wicara menghambat kemampuan seseorang memproduksi ucapan (perkataan) yang sejatinya terpadu dari pita suara, lidah, otot-otot yang membentuk rongga mulut serta kerongkongan, dan paru-paru. Hal ini disebut gangguan mekanisme berbicara. Menurut Chaer (2002) berdasarkan mekanismenya, gangguan berbicara dapat terjadi akibat kelainan pada paru-paru (pulmonal), pada pita suara (laringal), pada lidah (lingual), serta pada rongga mulut dan kerongkongan (resonental)

Pada kategori kedua, gangguan berbahasa terjadi karena adanya gangguan berkognisi. Hal ini terjadi pada orang yang pikun (demensia), penderita sisofrenia dan depresif. Pada penderita demensia, gangguan berpikir menyebabkan ekspresi verbalnya diwarnai dengan kesukaran menemukan kata-kata yang tepat. Kalimat seringkali diulang-ulang, 
pembicaraan sering terputus karena arah pembicaraan tidak teringat atau sering berpindah ke topik lain. Artikel ini menitikberatkan pada kekurangmampuan berbahasa pada anak, sehingga gangguan akibat demensia tidak dibahas secara detail.

Sisofrenik dan depresif mengalami hambatan dalam melakukan curah verbal yang sesuai dengan konteks akibat gangguan berpikir. Curah verbal deprefis umpamanya, dicoraki topik yang menyedihkan, menyalahi dan mengutuk diri sendiri, kehilangan semangat bekerja dan gairah hidup, tidak mampu menikmati kehidupan, malah cenderung berupaya mengakhirinya.

Contoh yang disebutkan di atas jarang ditemui pada anak-anak. Gangguan berbahasa karena kognisi yang lebih umum ditemui yaitu pada penderita Down Syndrome dan Autisma. Pada penderita Down Syndrome kemampuan intelektualnya sangat beragam dan salah jika kita menganggap kemampuan berbahasa semua penderitanya sama. Menurut Kendler (Carrol, 1986:95) tingkatannya terbagi atas: ringan (IQ 53-68), sedang (IQ 36-52), berat (IQ 20-35) dan parah (IQ di bawah 20). Dengan demikian kemampuan linguistiknya mengacu pada kelainan kognitif yang dialaminya.

Kajian tentang Down Syndrome atau keterbelakangan mental menunjukkan adanya hubungan antara kelainan kognitif dengan kegagalan memperoleh kompetensi linguistik sepenuhnya. Secara umum perkembangan fonologisnya lambat. Hanya sedikit kosakata dapat dikuasai dan ucapannya cenderung pendek dan telegrafis (tanpa imbuhan dan kata sambung, mirip bahasa dalam telegram). Anak sindrom down juga bermasalah dengan pelafalan. Dengan suaranya yang khas parau, intonasinya tergolong abnormal.Komunikasi dengan menggunakan bahasa tubuh (gesture) lebih dipilih oleh anak dengan sindroma down berat dan parah. Adapun kemampuan sintaksisnya dapat dicapai pada usia dewasa, meskipun mereka lebih dapat menangkap kontruksi kalimat afirmatif daripada negasi.

Secara umum dapat disimpulkan bahwa gangguan berbahasa, yang dialami penderita sindroma down baik anak-anak maupun 
dewasa, hanya bersifat terlambat (bukan bersifat kurang atau tidak mampu). Artinya dengan perkembangan yang berlangsung lamban, proses pemerolehan bahasa yang dilaluinya mirip dengan urutan normal meskipun pada sebagian penderita tidak dapat mencapai kompetensi penuh sebagai mana pembicara dewasa normal. Hal ini tergantung tingkat parahnya kelainan yang diderita.

Pada kasus Autisma terjadi kombinasi antara kelainan kognitif dan sosial. Penyandang autisma bisa jadi membisu hingga usia lima tahun, atau hanya membeo kata-kata orang dewasa yang didengarnmya. Hal ini mengindikasikan bahwa penyandang autisma memiliki keterbatasan alam pikir, artinya mereka tidak mampu memahami dunia dari sudut pandang orang lain. Segala aspek komunikasi sulit dicapai penyandang autisma, kecuali aspek fonologis yang pada sebagian penyandang tetap dapat dikuasai. Perkembangan ketrampilan bahasanya tidak saja mengalami keterlambatan tetapi juga penyimpangan.

Secara fonologis, artikulasinya cukup jelas meskipun sering muncul beragam kesalahan dalam penyebutan obyek. Misalnya substitusi atau menyebut dengan kata lain, menghilangkan suku kata tertentu, asimilasi dengan kata lain, menambahkan dengan suku kata yang salah. Intonasinya cenderung datar dan salah dalam membuat penekanan ucapan. Kemampuan sintaksisnya sangat lamban karena sering muncul kalimat peniruan atau echolalia, yaitu mengulang-ulang kalimat yang tidak relevan dengan konteks. Kemampuan memahami semantik juga lamban, misalnya membedakan antara "The girl feeds the baby" dengan "The baby feeds the girl".

Pada kategori ketiga, anak dapat mengalami gangguan berbahasa secara linguistik yaitu ketidakmampuan dalam pemerolehan dan pemrosesan informasi linguistik. Misalnya masalah kefasihan yang terjadi pada anak yang gagap dan latah atau pada penderita gangguan fisiologis yang menyangkut kesalahan formasi dan pengolahan organ artikulasi (seperti mulut, lidah, langit-langit, pangkal tenggorok dll.). Selain itu anak dapat menghadapi masalah baca tulis. Disini perlu 
dibedakan antara disleksia dan disgrafia. Disleksia atau kesulitan membaca kerap diikuti dengan disgrafia atau kesulitan menulis. Tingkat kelainan dan gejalanya bervariasi antar individu. Sebagian penderita disleksia juga mengalami keterbatasan fonologis misalnya tidak bisa menduga bagaimana membedakan ejaan kata atau bukan kata. Penderita lain sekedar menghafal ejaan kata dan tidak dapat mengingat ejaan kata-kata lain. Secara umum penderita disleksia mengalami kesulitan pada area kognitif tertentu, termasuk membedakan kiri/kanan, barat/timur; juga konsep waktu seperti hari, tanggal, bulan, tahun; serta pengolahan secara matematis.

\section{Penutup}

Dari paparan di atas dapat disimpulkan bahwa kemampuan berkomunikasi ditunjang dari proses pemerolehan kecakapan berbahasa. Kompleksitas bahasa menuntut akumulasi pemerolehan yang juga berkesinambungan dari tataran tersederhana hingga yang membutuhkan gabungan kemampuan berbahasa dan bersosialisasi. Mata rantai pertumbuhan kemampuan berbahasa tidak seragam pada satu orang dengan orang lainnya. Variasi inilah yang menghasilkan perbedaan pencapaian kemahiran kognitif yang difasilitasi kompetensi dan performasi berbahasa. Mutlaknya kebutuhan akan kemampuan berbahasa membuat tidak tepatnya sebutan ketidakmampuan berbahasa -melainkan menyebutnya sebagai kekurangmampuan berbahasa. Kekurangmampuan ini hanya bersifat gangguan atau keterlambatan berbahasa yang melampaui masa emas pemerolehan bahasa. $\square$ 


\section{DAFTAR PUSTAKA}

Carrol, David W. 1986. Psychology of Language. Pacific Grove-California: Brooks/Cole Publishing Company.

Field, John. 2003. Psycholinguistics: a resource book for students. New York: Routledge.

Fromkin, Victoria; Blair, David and Collins, Peter. 1999. An Introduction to Language. Sydney: Harcourt, Ltd.

Gleason, Jean Berko dan Ratner, Nan Bernstein. 1998. Psycholinguistics. Victoria: Wadsworth Thomson Learning.

Hatch, Evelyn Macussen. 1983. Psycholinguistics: a second language perspective. Rowley: Newbury House Publisher, Inc.

Pusponegoro, H.D. 1997. Apakah Perkembangan Anak Anda Normal? Dalam Simposium Autisme: Gangguan Perkembangan Pada Anak. Jakarta: Yayasan Autisme Indonesia.

Sutardi, Rudi. 1997. Autisme: Gangguan Perkembangan pada Anak. Dalam Simposium Autisme: Gangguan Perkembangan Pada Anak. Jakarta: Yayasan Autisme Indonesia.

Subyakto-Nababan, Sri Utari. 1992. Psikolinguistik: Suatu Pengantar. Jakarta: Gramedia Pustaka Utama 